\title{
抄録
}

ルー・ウォーカー：斜面地形モテルと土境生成（開 いた系および用した系として）

Ruhe, R. V. and Walker, P. H. (1968) : Hillslope models and soil formation I Open sytems Trans. 9th Intern. Congr. Soil Sci. 4 551560

Walker, P. H. and Ruhe, R. V. (-): ditto II Closed systems ibid. 561-568

斜面に俥いている地形的なフロセスの少くとる一部は そのまま，そこにおける土壤生成過程でもある。低次の 水系, すなわちより高次の谷に向って開いた支谷で， 谷壁斜面の侵赨によりるたらされた堆栍物の一部は流去 してしまうので，一種の開いた系を形成していることに なる。閉塞凹地ではそのようなことはなく，閉した系が 形成されている。開いた系の場合, 斜面は3つの地形要 素 (head slope, side slope, nose slope) がある。各地 形要素は5つの地形断面要素 (summit, shoulder, backslope, footslope, toeslope) から成る（これは閉し た采の斜面でる同様)。各地形断面要素は 傾斜の不連続 的変化によって画定されるが，必ずしるあらゆる㑯向が すへての地形断面要素をるつわけではない。

開いた系の適用される例として選ばれたアイオワ州 Adair と Harrison については，筆者の一人 Ruhe に よって既に編年的研究が行なわれている。前者は14,000 年 B.P.より古いレスの堆栍面を summit とし，それを 切る斜面は 6,800 年 B.P. より若いことが谷底堆栍物下 底部の試料の C-14 年代加 わかる。起伏は 20〜30ft., 平均倾斜は996である。後者の summit はおそらく 14,000 年 B. P. くらい, 起伏 50 60ft., 平均㑯斜 $23 \%$ である。両地区の summit から backslope に至る数本の 断面上の数地点で土劉形態の各要秦を測定した。これら を各地点の㑯斜の関数としてあらわすと，粘土含量か最 大になる深さや土䦎の厚さは，両地区の年代や起伏，㑯 斜の连いにるかかわらず，とるに $\mathrm{Y}=\mathrm{a}+\mathrm{b}_{1} \mathrm{X}+\mathrm{b}_{2} \mathrm{X}^{4}$ の形になる。これは shoulder でう傾向を示す直線 $\mathrm{Y}=$ $\mathrm{a}^{\prime}+\mathrm{cX}$ と backslope での倾向を示寸直線 $\mathrm{Y}=\mathrm{a}^{\prime \prime}+\mathrm{b}_{1} \mathrm{X}$ とを接䋨したもので，その座曲点は，物躓移動の少ない 安定な古い summit と不安定な若、 hillslope との不協 和的接綂を示す もの上考えられるこj上うに2つの地

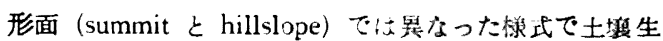

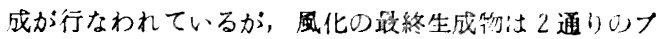
ロセスの結合したもので，それは㷙晄の多項式であらわ される。

閉じた系们場合は，斜面の侵蝕史が堆䅪物として完全 に保存されている。例として翼んたアイオワ州 Colo お よび Jewell は，ともにウィスコンシン氷期後期の水科 物の表面にある閉塞凹地で，筆者の一人 Walkerによ る詳細な編年的研究がある。両地区の斜面と6最近約
13,000年間侵蜻をうけていて，その結果露出した石灰贫 の水積物か土土境母材になっている。後水期の森林時代の 初期 $(8,000 \sim 3,000$ 年 B. P. ) に Colo では平均 $1.7 \mathrm{ft}$., Jewell では平均 5.3ft の厚さの土壤か捈面 上部から除 去されたと推定され，その時の森林破壊の結果フレイリ 一的堆栍環境が出現した。地形からみて，斜面下部ほど 堆積物か㴟く細粒化している一方，土局の発達は summit で最良，backslope で最琹で，堆䅅部の中心に 向って有機炭来含量が增し，岸酸塩の出現する深さは shoulder で最も浅いことが予想される。両地区の summit〜backslope 上の数地点で得た上記土壤形態各要素の 測定値を分水界からの距蜼の関数としてあらわすと，い ずれる $\mathrm{Y}=\mathrm{A}+\mathrm{BX}+\mathrm{CX}^{2}+\mathrm{DX}^{3}+\cdots$ ( $\mathrm{B}, \mathrm{D}$ と $\mathrm{C}, \mathrm{E}$ は 異符号) の形になり，前記の予想と一致する。したが ってこのモデは一般に閉した系をあらわするのと思わ れ，実際にアイオワ州内の他の閉塞四地内の地形・土壤 の傾向の予測に用いられた。るっと大規模な閉塞水系に 对しても適用できるのではないだろうか。

上述の開いた系・閉した系両方の例から明らかな上う $に$, summit-hillslope の采は, Nortor \& Smith (1930) 等の言うような，斜面上の位置によって水分環境が異な ることだけが土墱生成に效いている単純な系ではなく， Milne（1936）が指摘したように，現在の営力および発 達史をも含む複雑な系である。

(田村俊和)

\section{ヒュベリネン：ヒエエルネヤ島の湖から得られた第四 跑末の堆程物コア}

Hyvärinen, H. (1968) Late-Quaternary sediment cores from lakes on Bjørnøya Geogr. Ann. 50

A $236-245$

Bjørnøya はノルウエーの北約 $440 \mathrm{~km}$ の Barents shelf 西縁にある Caledonian remnant である。本島にある多 数の湖より18を選ひ，堆程物のコアを採取した。そのの うち 4 つのコアについては花粉分析・迋藻分析が行なわ れ，C-14 年代測定は1つのコアについて行なわれた。 コアの基底は角レキを含むシルトからなり，その上位に シルト䁈泥土の湖成堆程物がのっている。基底シルトと

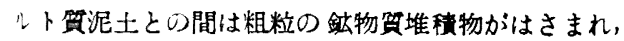
シルト筫泥土の中部には黒色带状のサルファ！トがはさ まれている。

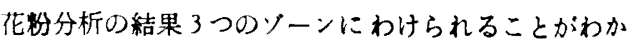
った。下位から順に I, II, III, とすると，I は姫な NAP で特徴つけられるが AP では Betula が卓越し， Salix は他の部分と比較すると最も多い。II は NAP が少なくなり，AP では Alnus が上年する。更に中部 の NAP の增加により下位より a， b c c D 3 部にわけ られる。III は再ひ NAP の值か漓くなり，AP ては Pinusが卓越する。Picea の花粉は I/II, II/IIIの渐 
移曾付近に存在する。現在の気侯条件下で AP は口 一カルな䫖てはなく，NAP の大部分なローカルな植 生に由来している。AP 变化はフェノスカンディアにお

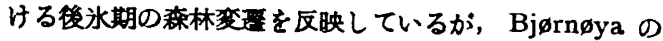
花粉が風で荤ばれたるのか、ローカルに生成したるのか は依然として符問のままである。C-14 年代測定は1つ のコアの3部分で行なわれたが，いずれる統計俱差が大 きく今得詳相な測定が必要であるが,このコアが 10,000 年 B.P. 以後に堆稘したもの，そして晚水期・後水期の ちのであるとの結論は引き出せる。进湿分析は湖成堆程 物と海成堆榬物の区別のために行なったが竝対数が少な

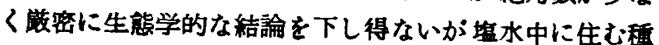
は存在しない。

以上のことから次のようなことがいえる。基底シルト からシルト䁈泥土への移行，すなわち湖中への有機質堆 稜物の堆移開始は非水河状態の開始を表わしており， 汪 『10,000年 B.P. という值がのことを裹つけてい る。湖成堆䅅物中, 最上部之最下部の泥土は酸化状態を 示すが，中部には還元されだサフフイトが存在し，最 る厚く堆榡している。この事实と花粉分析の結果による mediocratic なエピソードの一政は重要である。つまり 堆稜中の上年は中部のサルフ>イド泥土の堆稜期間中に 起ったしそそれが mediocratic な時間に相当するとい うことである。またスバールバ諸島の Hopen, Kong Karls Land の島マに見られるような高く隆尼したビー チは存在しない。これは仮に Barents shelf が大水床で あり，Bjørnøya がその一部であったとしてる，西烼に ある Bjørnøya は皮床あるい:沈その後のアイソスタシ 一の影籍を影辺的にしか蒙らなかったと考えられる

(千田留)

\section{大矢: メコン川洁域パモン下洼地域の地形と洪水}

Oya, Masahiko (1967) : Geographical study of flooding immediately down-stream from Pamong in the Mekong river basin The Committee for Co-ordination of Investigations of the Lower Basin, ECAFE 64ps.

メコン川中下流域で洪水は，日本の洪水の多くと異 なり，始まってから釉る迄の期間か長く，大規模であ る。この川は洪水を毎年のように起こし，特に1966 年 のちのは解測首料のある期間で1,2であった。この研究 の主目的はメコン川流域平野での洪水状況を把幄し，今 後起こりうる洪水の予想をし，洪水調節の基礎とするこ とである。

平野の微起伏が洪水の繰返しにより形成されて来てい るから，微地形や砂磁の堆稳状況を見れ注過去の洪水の 性贫を知ることができる。メコン川中下流域の開発計画 を立てるには水盗源についての大規槙計画を伴い，洪水 調節は不可欠である。けれどる料殆どなく收集は困 嚾である。ところが地形分類园を判䛃することにより， 洪水状況を予測でさ，上中流の洪水調節を行うための基
碤瓷料にてきる。この罒は他に潧溉などにる使える。1966 年の大洪水を主にして地形と洪水の関係を明ら功に， 以下に要点を記す。

1. 1966 年の大洪水の気像的原因はメコン川上流地域 の萧雨による。2. 洪水位は $12.71 \mathrm{~m}$ から $13.82 \mathrm{~m}$ を示 し，地点によって過去1，2番目てあった。これはメコン 中流域より上流側で例年より多雨であったことを示す。 又多くの支川と盆地をるつことにもよっている。3．自 然堤防 ·旧河道の全域 ·低位段丘の一部力冠水した。 れは洪水の規模が沖秷世で最大棅のものであることを示 す。4. ウィエンチャン付近の地形分類四を作成した (付図)。5. 洪水の流向により 2 通りに分けられる。即 万河道加ら周囲人湓れる型と河道へ集る型であ。6.ウ イエンチャンとノンカイは稀に見る大洪水の時冠水す る。7. メコン川は F. A.O. のパイロットファーム付 近で曲流している。洪水は河道沿いでなく自然堤防に並 行して進んた。。FAO農場の堤防は侵食が進み，Pamong 夕八建設迄続くから 10〜20m 後退させてつくりなおし た方がよい。8，洪水による大量のシルト，粘土等の流 送物筫は自然堤防上で $30 \mathrm{~cm}-160 \mathrm{~cm}$, 後背湿地では 3 $\mathrm{cm}$ の厚さである。両地形とる洪水のくりかえしでできる゙ ことを示す。9. 地形分類困と1966 年の 洪水状況园を 比へると多くの場合に浸水型と地形の密接な関倸が られ, 組み合せて, 下流型 - 谷底平野型·自然堤防 - 後 背湿地·三角州型・市街型 - 盆地型に分けた。10. 浸 水型と被害型との間に密接な関係がある。11，洪水 地形加見て Pamong 夕厶㥏力・整溉 ·水調節に必 要である。

（赤桐毅一）

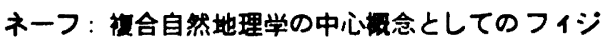 オトーフ}

Neef, E. (1968) : Der Physiotop als Zentralbegriff der Komplexen Physischen Geographie

Peterm. Geogr. Mitt. $112 \quad$ 15-23

様々な要素の組み合せを通して䫟れる物莓的なシステ 么の探求は，言わは「複合自然地理学」とでも言えるが， その対象は，高欧な綜合段階の自然空間であって，限定 された条件の下の探求であろ通常の個別科学の解析方法 では充分でなく，綜合された対象を解析する特別な力法 が必要である。そのために，自然空間に於ける綜合像と しての単位の設定が必要であるが，その単位として，まず 立地基本位置（site）と生物の被復（cover）を綜合した Ökotop なる槩念を考える。しかし， Ökotop は生物の 形態が非常に多梯で，複雑な物質を考虑せねばならない 上に，人間によって生物界が大き改变されているの て， 相互の比較の可能性が限定されるという解析に於计 る困嚾点がある。これを回避するために設定されたのが Physiotop で，その定義は，すでに「無機的桡成物と， 与えられた範囲内の物莓の収支の展開とで示される地理

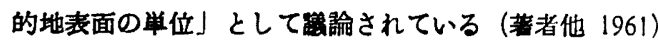
この Physiotop は，具体的には3つの基本指儛である 
地因子, 即ち，(1)岩石及び土裹，(2気候，(3土壤水分， の結合を通して表現される綜合体であって，その定義か ら，(1)地理的単位を示し，地域的粠造を呈示する。(2)要 素の自然法則的結合を描写する。錯綜性（要素の多様 性の度）及び複合性（部分系の組み合せの度）を表現 する。(4)指標の量的取り扱いかできる。(5)類型学的方法 が適用できる。6均質的かつ複合して異貿的地域結合々 なる単位を表現している。(7)自然地理学の種々の見方 (機能的·形態的 ·生成的等) の下で有用である。包 括的な抽象度をるつ，等の性質を持ち，それ故に，襩合 自然地理学に於计る基本的概念已見做され得る。亦, Physiotop が Ökotop に比してるつ方法論的な差異とし てまず第一に，物理学的法則と生物学的法則の 2 つの因 果形態に属している Ökotop の方法論的絾密さの久除を 回避している点が挙げられるか，その他に，抽象化の程

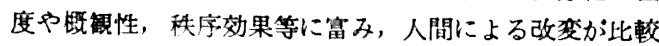
的少く，総して，戦密な自然法則的基硭の上に定義され た茨であるので，相対的に安定した指標への限定·定量 化·公式化の可能性をより强く有していると呚える。

以上のようなことを考慮して，Physiotopは，「相対 的に安定した自然法則的变動中に存在する無機的因子に よる, 景観生態学的基本単位の表現」として公式化され る。

(杉浦值)

\section{シンプンン：ナィジェリアの罗牲産}

Simpson E. ১. (1969) : Electricity Production in Nigeria Econ. Geogr. 45 239 257

電力生産の状況は，その国の工業生産·生活水澡の指 標である。そしてその開発は，開発途上国では，地域開 発の基幹をなしている。本論では，ナィシリアにおける 電力開発の過程·電力生産の配置・開発上の問題点を监 らかにしたい。

ナィジエリアの電力生産は，1898 年植民地政府により 首都ラゴスにおいて始められ，Zの発電量は，第2次大 戦後急速に增大している。すなわち，1939 年当時 15 百 万kwhにすきなかった発電量か，1953年に94.5 百 万 kwh，1966年には1064百万 kwh と戦前J门倍に伸 ぴたこのような過程において，電力生産・供給の一元 化, 大規模発電所の建設, 電源の多様化が進められてい る。まず1950年に，電気事莱法か施行され，2っの自 家発電所を除く全発電所か，国觉のナィシエリア電力の 平下におかれ，電力生産・供給の一元化が行われた。次 いで, 1959 年には，カインシ，シエパ，シロロの3々所 のタ健設が決定した。これらのダムは，多目的ダで あり, それそれれ発電能力は，960メガワット，200メガ ワット，480メガワットである。そして，シ口ロと他の 2つのタムとは，それ弪れの流域における相互補完的な 雨期の差を利用して，全体として安定した電力低給が行 えるように体系化されている。

ナィジリア電力は，これらのタムで発電の周始され ろ1969 年までの間, 需要の增加に対応してゆくため電
源の多栐化を積極的に押し進めてきた。その結果，1955 年当時, 全体の 53.5\% を占めていた石炭火力は, 66 年 には15.996減少し，代ってガスタービン発龟が全体 の 29.396を占めるに至った。

こうした電源の多様化と電力需要の増大は, 電力生産 の配置を徐々に変えてきている。1939年当時は, ラゴス が全体の 53.396 を占め, これにクラ, カノ, サベーリ がつつきこれらでほほ100\%を占めていた。それが 1953年には，ラゴスの割合が全体の約 1/3に減少し， シ オス!フラトー (30.4\%), イバン (9.8\%), カーノ (-.6\%)，エヌグ (6.5\%) がこれにつつききこれらが全 体の約 $95 \%$ を占めるように变ってきた。そしてこのよ うな橡相は，アファムでのガスタービン発電所の立地, 綿工業の中心地カーノでのディーゼル発電の增強によ りますます強められている。

こうした電力生産の分散化は，需要の增大に応してて国 策的に行われており，必ずしも収支のハラランスはとれて いない。とくに電源から離れ，需要地の散在している北 部地区では，それが著しい。これを解消するため, 前述し たナィシェリアダム開発が押し進められているか，そ の電力を効象的に利用する目的で計画されている $330 \mathrm{kv}$ 送電網については，需要規模の点で問題が残っている。

（宮川泰夫）

\section{ユンクハンス：伝较的な糗業社会に与えるエ業化の 影管}

Junghans K. H. (1968) : Einfluß der Industrialisierung auf die geographische und geistige Mobilität traditioneller Agrargesellschaften in Südasien Grographische Rundschau 11 423431

社会経済的な変革から取り理された，後進的な農業社 会を如何に近代化するかという問題は，しばしば工業化 と並列に論論される。この考えはある意味で後進地域開 発の経済政策的理念の।つともなっているか，具体例に 即して充分な検証が要請される。この論文はそのような 観点から，ハイデルベルク大学南アジフ研究所が中心 なって， Rourkela の後背地を対象に行なわれた大規模 な调查ひうち，主要な問題点一伝統的な農業社会の可動 性一についての中間報告である。

1. 地理的可動性に与える工業化の影䅧（5つのZone には分して描くことが出来る)

Zone $1(6 \mathrm{~km}>)$ Rourkela の市街地と製鉄工場建设 前の郊外を取囲む地域。道路網は良く整備され，多くの 交通手段があるので，コミュニケーションは容易。全所 䓵が工業ないし非農業的収入を得ている。Zone 2 (12km?）都市域と道接接するが居住の形態は明らかに 区別され，住民は独立した家屋に住む。铁工学的者の大 部分は徒歩で通勤する。全所带の 46.4\%は工莱功の

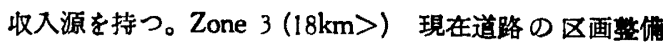
が行なわれているのか特色。工場労倾者の多くは自枟車 
で通勤。工莱収入のある所带は 全体の $31.2 \%$ 以下。雨 季になると船舶の密な交通網が形成される関係から固定 した道路の数は少ない。Zone $4(40 \mathrm{~km}>)$ 労㲜者の工 場通勤は困雜となり，ウィークデーは都市に住み，週末 には村に住し家族のもとに帰るという就労形態が卓越。 工莱收入を持つ家は 20\% 程度。Zone $5 \quad(40 \mathrm{~km}<)$ 遠 方から Rourkela 一勤める労㑛者には週末の疤省さえも 雜かしく，それ故に家族の一時的な都市居住が進む。

以上のような Rourkela 周辺にみられる明らかな地理 的可功性は，伝統的な農業社会の連带性を摘みとる一方 工業化に対応した活発な精神的協力関係を助長する。

2. 精神的可哩性に与える工業化の影響

社会的に規則性を持つ伝統的な農業社会の結合関係が 根本的に変化する過程は未だ明らかにされてはいない。 しかしなかららここに調査結果から得た2つの非常に重要 な現象を指摘しよう。(1物質的価値構造の变化。とくに 従来から多くの農村にみられる場合と同棣 Rourkela の 後背地においても，繁栄の主要な標識であった土地所有 が，例えば教育観などに対して，その重要性を低下させ ている点に象徽される。(2)農家の経営経斉的事情门变 化。この地域において，収益增加の伝統的な手段てあつ た漼溉は貿問者中の3 分 2 で放裹され, 代って化学肥料 の使用が多くなっている。このことは, 豊家が生産手段 の評価にあたってかなり経斉的合理性を重視するように なっていることを示すちのといえる。

上記に加えて，農村か门工場誘致に積極的に乘りたし， 多くの潜在労㑬力を工場に供給していることから， Rourkela の後背地においてはて工業化による侵進地域 の開発が成功している上いえよう。

$$
\text { （元木 请） }
$$

\section{ロパートソン：地誌についての児宜の理解}

Robertson, B. S. (1968) : Children's Understanding Journ. Geogr. 67 152 155

地誌に対する児童の理解と諗識についての調査の一部 で，調査対象の子供は，大ロンドン区域内の学校の能力 的に中以下の 14 才の子供である。資料は，彼らとの自 由会話による個別的な面接の結果の分析である。それら
倍 正

謁 (本号論文として掲載)

济原地方の和紙業（その2） 会田隆昭・杉浦 㨁
田沢及ひ第 2 田沢硫水事業と量钼变化

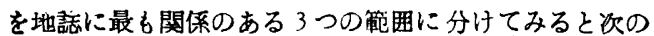
ような結果となる。

I. 地理学の性筫 (1) 汃なりの子供が，地理学を国 や世界に結びつけている。（2）子供の約 $1 / 3$ たけが，地 理学と描写とを関連させている。（3）繁くことに，人々 の生活について言及しているのは子供の1/3だけであ り，（4）地理学者か重要視している問題の論究や他の㒫 地は低い数字である。

II. すでに学習した地域の祐述や具体化する能力

(Detail of, or ability to visualize regions studied) ていない者や，全く具体化する能力の無い者か，過半数 であり，不完全ではあるが具体化しうる者は一部でしか なく、この点では著しく久陷を示している。

III. 域地睞念の理解 (1) 地域の観念について完全 に無知なるの (3396)，(2) 自然地域ではなく，上く知 られている地区を区分する能力のあるもの (38\%)，

（3）自然地域の镌念を知っているるの (21\%)，(4)上く 知られている地区を地域に区分する能力のあるるの （7\%）となり，彼等が述へた地域を類別すると，政治的 りもの (38\%)，植物によるもの (23\%)，経風的のちの （18\%)，起伏によるもの (15\%)，気候によるもの(5\%)， となる。

この結果から，子供たちは，他の区分が可能であるこ とに気ゔいてはいても，初めは政治的領域で考えるよう に思われる。

地域の忩合は梅墔な学術的過程であるから，以上の事 柄は整くべきことではないかもしれないし，また，子供 たちの久陷は，それらの硯念を把握するのに無力なせい か，あるいは彼らが受けた授業のせいかどうか，まだ確 かではない。一方, 他の調査では, 子供らが, “場所” について考えられるし，また考えうる事を示するのがあ る。

地域概念の基本的な最少事か，場所の学習である限 り，子供たちの中に自然景银や文化景観を具体化しうる 能力を発展させる方向に向かって，授業が行なわれるよ うにすべきことは明らかである。

(田辺健一，浅野葉子)
すでに学習した場所の現実について，何ら概念をもっ

東北地理 22 巻 1 号 54 頁 30 33 行

II:

田沢及び第 2 田沢硫水事業と景観变化 (本号論文として揭載)

杉浦 们

荡原地方の和紙業（その 2) 